\title{
FACTORS RELATED TO SELF-CARE ACTIVITIES ADHERENCE OF OLDER ADULTS WITH DIABETES
}

\section{FATORES RELACIONADOS À ADESÃO ÀS ATIVIDADES DE AUTOCUIDADO DE IDOSOS COM DIABETES}

\author{
Glenda DYONISIO'; ${ }^{1}$ Natália Gomes VICENTE²; Luiza Maria de ASSUNÇÃOª \\ Nayara Paula Fernandes Martins MOLINA ${ }^{4}$; Leiner Resende RODRIGUES ${ }^{5}$ \\ 1. Mestre em Atenção à Saúde, Universidade Federal do Triângulo Mineiro, Uberaba, MG, Brasil; 2. Doutoranda em Atenção à Saúde, \\ Universidade Federal do Triângulo Mineiro, Uberaba, MG, Brasil; 3. Pós-doutora em Atenção à Saúde, Universidade Federal do \\ Triângulo Mineiro, Uberaba, MG, Brasil. luassunc@gmail.com; 4. Doutora em Atenção à Saúde, Professora Substituta do Departamento \\ de Enfermagem e Educação em Saúde Comunitária, Universidade Federal do Triângulo Mineiro, Uberaba, MG, Brasil; 5. Doutora em \\ Enfermagem, Professora Associada do Departamento de Enfermagem e Educação em Saúde Comunitária da Universidade Federal do \\ Triângulo Mineiro, Uberaba, MG, Brasil.
}

\begin{abstract}
Diabetes mellitus treatment is complex and involves several activities. Its goal is to control the disease and prevent complications. The success of this treatment includes adherence to self-care. This study aimed at identifying factors related to self-care activities adherence in community older adults with diabetes. Cross-sectional, observational and analytical study with a quantitative approach to data, conducted with 140 older people. We used the following instruments: Mini-Mental State Examination for cognitive assessment, socio-demographic and clinical characterization instrument, Brazilian Functional and Multidimensional Assessment Questionnaire to verify the self-reported morbidities, Abbreviated Geriatric Depression Scale to investigate the presence of depressive symptoms and Diabetes Self-Care Activities Questionnaire to assess activities adherence related to self-management of people with diabetes. The results of this study indicated that self-care activities with higher adherence were: "taking the indicated number of diabetes pills" ( $6.6 \pm 1.2)$, "taking insulin injections as recommended" $(6.2 \pm 2.0)$, "drying the spaces between the toes after wash them" $(4.6 \pm 3.2)$ and "following a healthy diet" $(4.5 \pm 2.7)$. The self-care activities with smallest adherence were: "performing specific physical activities (walking, swimming, etc.)" (0.9 \pm 1.9$)$, "performing physical activities for at least 30 minutes" $(1.2 \pm 2.2)$, "evaluation of blood sugar as times as recommended" $(1.2 \pm 2.3)$, "sweets intake" $(1.3 \pm 1.7)$ and "evaluation of blood sugar" $(1.4 \pm 2.3)$. Regarding smoking, $88.6 \%$ were not smokers. Factors related to self-care measures were: gender, indicating greater adherence of women, education level, and number of morbidities, suggesting that adherence to the feet care domain is directly proportional to education and number of morbidities. However, this same domain was inversely proportional to depression, indicating that there was greater adherence in those people without depressive symptoms. The factors associated with the adherence to self-care activities observed in this research contributed to the planning of strategies to prevent diabetes mellitus complications and promote improvements in the life and health of the older adults in the community.
\end{abstract}

KEYWORDS: Health of the elderly population. Diabetes Mellitus. Self-care Cooperation and adherence to treatment.

\section{INTRODUCTION}

Diabetes mellitus (DM) is a multifactorial disease of high incidence and prevalence worldwide, characterizing this clinical condition as a worldwide epidemic. Therefore, it is a major challenge not only for public health and health professionals but also for society (FARIA et al., 2013; INTERNATIONAL DIABETES FEDERATION, 2013a).

DM treatment often uses medications associated with a change in lifestyle. The adoption of balanced eating habits, regular physical activity, foot care, disease monitoring, and compliance with the routine care provided by the health service are some of the non-medication measures related to the DM treatment (AMERICAN DIABETES ASSOCIATION, 2015; BRAZILIAN SOCIETY DE DIABETES, 2016). Such behavior is called selfcare. Self-care includes the activities the individuals perform to maintain their health and well-being. These activities are related to the skills developed during the disease evolution (BUB et al., 2006; WEINGER, BEVERLY, SMALDONE, 2014).

The treatment adherence directly contributes to the successful control of DM. Some factors may influence this adherence. The main difficulties for the self-care practice are the advanced age, low 
educational level, low-income, lack of family support, emotional factors (frustration, demotivation, pain, anguish, anger), and cultural factors (ONG; CHUA; NG, 2014).

For the World Health Organization (2003), other factors that influence the treatment adherence are the demands related to the disease, such as the evolution and worsening of the disease and its symptoms, the degree of physical, psychological or social disability, the availability of treatment and the presence of comorbidities, especially depression (ROY; LLOYD, 2012).

The DM and depression together may be related to poor glycemic control, presence of complications, a higher number of hospitalizations and premature death. This is because these individuals tend to have low adherence to self-care treatment and activities (DIAS et al., 2011; LLOYD, 2008; WEINGER, BEVERLY, SMALDONE, 2014). Depression is prevalent in the older population, being an underdiagnosed chronic disease, as its symptoms are usually confused with the reactions of individuals to the disease or with typical events of aging (PARADELA, 2011; SOCIEDADE BRASILEIRA DE DIABETES, 2014).

The complexity of DM treatment requires that individuals adhere to self-care activities to control blood sugar and prevent complications, contributing to the maintenance of the individual's quality of life and autonomy. From this perspective, nursing has the important mission of encouraging adherence to self-care through health education actions, encouraging changes in life habits, facilitating the development of skills, and evaluating competencies for self-care activities (REZENDE NETA; SILVA; SILVA, 2015).

However, there is still a lack of studies in this area since it is important to deepen the topic to understand the reality of self-care in the elderly population (SILVA; VIDAL, 2011). Therefore, this study aimed at identifying factors related to selfcare activities adherence in community older adults with diabetes.

\section{MATERIAL AND METHODS}

This is a cross-sectional, analytical and observational study with a quantitative approach with a home questionnaire, developed as part of the larger study called "Depressive symptoms, associated factors and access to health services in the elderly residents in the Triângulo Sul Mineiro", conducted in the urban area of the city of Uberaba MG, from March to July 2016.
The sample of the largest study population was defined by a multiple-stage cluster sampling, carried out in two stages. In the first stage, an arbitrary draw of $50 \%$ of the census tracts of the municipality was conducted through systematic sampling for the selection of the elderly population, organizing a unique listing of the sectors, but identifying the neighborhood they belonged. The sample interval (SI) was calculated by the formula: $\mathrm{SI}=\mathrm{Ncs} / \mathrm{ncs}$; in which Ncs is the total number of census tracts and ncs is the number of census tracts drawn (approximately 2). The first census tract was randomly drawn, and the others were selected according to SI.

In the second stage, the number of homes was given by the number of attempts previously calculated $(n=889)$. Then, this number of homes was divided by the number of census sectors drawn (208 sectors) so that a similar amount was obtained within each census sector (approximately four older people per sector). Finally, data collection began at the first street home within each census sector, according to maps obtained by the IBGE of Uberaba going clockwise until the end of that sector. All homes were visited sequentially until the sample saturation (number of older people) of that sector.

There were 769 older people interviewed in the larger study. Of them, 153 showed cognitive decline and were excluded from the study. In 616 older people who met the inclusion criteria and were fit for the interview, 140 self-reported the diagnosis of DM, as established in the inclusion criteria of this study. Therefore, the sample of this study was composed of 140 older people.

The sample size calculation of this survey considered a determination coefficient of $\mathrm{R}^{2}=0.10$ in a linear regression model with four predictors, with a significance level type I error of $\alpha=0.05$ and type II error $\beta=0.1$, resulting in a priori statistical power of $90 \%$. We used the Power Analysis and Sample Size (PASS) version 13 application, obtaining a minimum sample size of $n=144$ of elderly participants. Considering the sample loss of $20 \%$, the maximum number of interview attempts was 180 . The main outcome variable was the adherence score for general food.

Thus, 140 older people who met the inclusion criteria participated in this study. They were 60 years old or older, self-reporting a diagnosis of DM, and having a cut-off score in the cognitive assessment through the Mini-Mental State Examination (MMSE).

Data collection was performed at the homes of the older adults through interviews and using five instruments: socio-demographic and clinical 
characterization instrument, Mini-Mental State Examination (MMSE), Brazilian Questionnaire for Functional, and Multidimensional Evaluation, Questionnaire of Self-Care Activities Diabetes (QAD) and GDS-15.

We performed the socio-demographic and clinical characterizations through a structured questionnaire prepared by the Collective Health Research Group of the Federal University of Triângulo Mineiro (UFTM), based on the literature and the researchers' expertise used since 2013 (RODRIGUES et al., 2017). It includes the following variables: age, gender, education level, marital status, income, and the use of medications, including the name of the active ingredient, presentation, dosage, amount used per day, and the number of medications in use.

We used the MMSE for cognitive assessment. Its score ranges from zero to thirty points, in which zero shows the worst cognitive performance and thirty indicates the best cognitive ability. The cutoff point considers the educational level, including in the study those older adults who presented the following scores: 13 for illiterate, 18 for one to eleven years of school and 26 for school level above 11 years (BERTOLUCCI et al., 1994). Self-reported morbidities were evaluated based on data from the 26 items included in BOMFAQ (RAMOS, 1987).

The QAD assesses self-care activities adherence with DM. It has 15 items distributed in 6 domains/dimensions: general diet, specific diet, physical activity, blood sugar monitoring, foot care, and medication use. It also presents a separate domain for smoking assessment. The answers in the questionnaire indicate how often respondents perform activities in the previous seven days and range from zero to seven, with zero as the least desirable and seven as the most favorable. The values are reversed in the specific food domain. In the items about the consumption of sweets and highfat foods, zero represents the ideal condition and seven represents the least favorable (MICHELS et al., 2010). Michels and collaborators in 2010 translated and adapted it to the Brazilian reality.

GDS-15 measured the indicative of the presence of depressive symptoms. It was proposed by Yesavage in 1986 and validated in Brazil by Almeida and Almeida (1999), consisting of 15 closed questions with objective answers (yes or no). For this study, a score higher than five considered indicative of the presence of depressive symptoms (ALMEIDA; ALMEIDA, 1999).
We entered the collected data in the Excel ${ }^{\circledR}$ Program in a double entry for later verification of the existence of transcription errors. Then, we consolidated the databases. When there were inconsistent data, they were verified in the original interview and corrected. Data were imported into Statistical Package for Social Sciences (SPSS), version 21.0, for analysis.

We submitted data to descriptive analysis using relative and absolute frequencies for categorical variables and measures of central tendency (median, mean, and standard deviation) for quantitative variables. The bivariate analysis included the t-test for independent groups defined by dichotomous variables and included gender, age group, presence of depressive symptoms, polypharmacy, marital status, and adherence to selfcare. Pearson's (quantitative variables) and Spearman's (ordinal variables) correlations were used to measuring the relationship between demographic variables (education level, income), clinics (number of morbidities) and adherence. The analysis of Pearson and Spearman correlations, a correlation corresponding to a coefficient $r$ between 0 and 0.29 was considered as weak, between 0.3 and 0.49 was considered as moderate and between 0.5 and 1 was considered as strong (COHEN, 1988). Analysis of the simultaneous contribution of demographic and clinical predictors to adherence included multiple linear regression analysis. This research considered the significance level of 0.05 .

This study followed the guidelines and regulatory standards of Resolution 466/12 of the National Health Council for research involving human beings (BRASIL, 2013b). The participants of this research were contacted at their homes, presenting the objectives, the Free and Informed Consent Form, and offering the relevant information. The interview started only after the consent of the interviewees and signing the Term.

\section{RESULTS}

Most of the participants being $71.4 \%$ (100) were female, $87.1 \%(122)$ were aged $60 \mathrm{~F} 79$ years old, $57.1 \%$ (80) had no partner, and $45 \%$ (63) of the elderly participants had an individual monthly income of one minimum wage (Table 1).

Regarding their age, the participants had a mean age of $70.8 \pm 6.7$, with a minimum age of 60 and a maximum age of 88 years old. Regarding their education level, the participants had a mean of $5.1 \pm$ 4.2 years of study, with a minimum of 0 and a maximum of 18 years of study. 
Table 1. Distribution of the elderly population with self-reported DM, according to socio-demographic and clinical variables, Uberaba, Minas Gerais, Brazil, 2016.

\begin{tabular}{|c|c|c|}
\hline Variables & $\mathbf{n}$ & $\%$ \\
\hline \multicolumn{3}{|l|}{ Gender } \\
\hline Male & 40 & 28.6 \\
\hline Female & 100 & 71.4 \\
\hline \multicolumn{3}{|l|}{ Marital status } \\
\hline married or living with a partner & 60 & 42.9 \\
\hline separated /divorced & 15 & 10.7 \\
\hline Widower & 56 & 40 \\
\hline Single & 9 & 6.4 \\
\hline \multicolumn{3}{|l|}{ Individual income (minimum wage)* } \\
\hline No income & 11 & 7.9 \\
\hline$<1$ & 1 & 0.7 \\
\hline 1 & 63 & 45 \\
\hline $1+3$ & 50 & 35.7 \\
\hline $3+5$ & 9 & 6.4 \\
\hline$>5$ & 6 & 4.3 \\
\hline \multicolumn{3}{|l|}{ Age group } \\
\hline Young elder ( 60 F 79 years old $)$ & 122 & 87.1 \\
\hline Extreme elder ( 80 years old or more) & 18 & 12.9 \\
\hline No & 55 & 39.3 \\
\hline Yes & 85 & 60.7 \\
\hline \multicolumn{3}{|l|}{ Indicative of depression } \\
\hline Yes & 37 & 26.4 \\
\hline No & 103 & 73.6 \\
\hline
\end{tabular}

* Amount corresponding to the minimum wage in 2016: $\mathrm{R} \$ 880.00$ (DIEESE).

Regarding the clinical variables, the average individual morbidity was $7.6 \pm 3.7$, with at least a self-reported morbidity and a maximum of 18 selfreported morbidities. The average of medicine consumption per individual was $5.7 \pm 2.9$. When considering polypharmacy, $60.7 \%$ (85) of the elderly participants used five or more medications, and $26.4 \%$ (37) of them showed depression.

Table 2 shows the adherence to DM selfcare activities, given by the average number of days the activities were performed. The evaluation of adherence in each of the QAD items compared the means between all activities, observing that the domains with the lowest adherence rate are physical activity and blood sugar monitoring, respectively. The domain with the highest mean adherence was the use of medications.

Item 7 of the QAD regarding the evaluation of smoking showed that $88.6 \%$ (124) of the elderly answered that they had not smoked any cigarettes in the last seven days. Of them, $67.1 \%$ (94) stated that they never smoked, and another $21.4 \%$ (30) said they had smoked their last cigarette for more than two years ago.
Among the $11.4 \%$ (16) who reported being smokers, the average consumption was $17.1( \pm 17.3)$ cigarettes per day.

A bivariate analysis showed that the items "performing physical activity for at least 30 minutes" ( $p=0.04)$, "taking insulin injections as recommended" $(p=0.02)$ and "taking the indicated number of diabetes pills" ( $p=0.02)$ was associated with gender, and in these items men had higher averages compared to women.

Regarding the average of diabetes self-care activities adherence according to the age group, the data showed no statistically significant difference in adherence to self-care activities between young and very old elders, indicating that age does not interfere with the adherence of any of the activities.

Regarding their marital status, the item "taking the indicated number of diabetes pills" ( $\mathrm{p}=$ 0.048) showed a significant difference in the average. Only in this item, those who have a partner showed better adherence when compared to those who have no partner.

Regarding polypharmacy, there was a significant association only with the item "examination inside the shoes before putting them 
on" $(\mathrm{p}=0.045)$, with a higher average of adherence

in the elderly who use five or more medications.

Table 2. Adherence to items of the Diabetes Self-Care Activities Questionnaire by elderly participants with Diabetes, Uberaba, Minas Gerais, Brazil, 2016.

\section{QAD Items}

\section{General food}

1.1. Following a healthy diet Variables

1.2. Following food guidance med.* average ${ }^{* *} \quad \mathrm{SD}^{* * * *}$

2. Specific Food

2.1. Intake of five or more servings of fruits and/or vegetables.

2.2. Intake of red meat and/or whole milk derivatives

2.3. Sweet intake

$\begin{array}{lll}5 & 4.5 & 2.7 \\ 3 & 3.3 & 2.9\end{array}$

3. Physical activity

3.1. Performing physical activities for at least 30 minutes

3.2. Performing specific physical activities (walking, swimming, etc.)

$5 \quad 4.4$

2.7

$5 \quad 4.4$

2.8

$1 \quad 1.3$

1.7

4. Blood sugar monitoring

4.1. Evaluating Blood Sugar

4.2. Evaluating blood sugar the recommended number of times

$0 \quad 1.2$

2.2

0.9

1.9

\section{Foot care}

5.1. Feet examination

$\begin{array}{lll}0 & 1.2 & 2.3\end{array}$

5.2. Examination inside the shoes before putting them on

5.3. Drying the spaces between the toes after washing them

$\begin{array}{lll}1 & 3.1 & 3.3\end{array}$

6. Medication

6.2. Taking insulin injections as recommended

6.3. Taking the indicated number of diabetes pills.

6.6

1.2

*Median; **Average of the days in the week for self-care activities; ***Standard Deviation.

The indicative of depression was significantly associated with the items of "intake of five or more portions of fruits and/or vegetables" ( $p$ $=0.039$ ), "performing physical activity for at least 30 minutes" $(p=0.017)$ and "performing specific physical activity (walking, swimming, etc.)" (p = 0.011), with higher mean adherence for the elderly population without the presence of depression. Adherence averages associated with depressive symptoms are shown in Table 3.

Table 3. Adherence to items of the Diabetes Self-Care Activities Questionnaire by older people with diabetes according to the presence of the indicative of depression, Uberaba, Minas Gerais, Brazil, 2016.

\section{QAD Items}

\section{General food}

1.1. Following a healthy diet

1.2. Following food guidance

2. Specific Food

2.1. Intake of five or more servings of fruits and/or vegetables.

2.2. Intake of red meat and/or whole milk derivatives

2.3. Sweet intake

3. Physical activity

3.1. Performing physical activities for at least 30 minutes

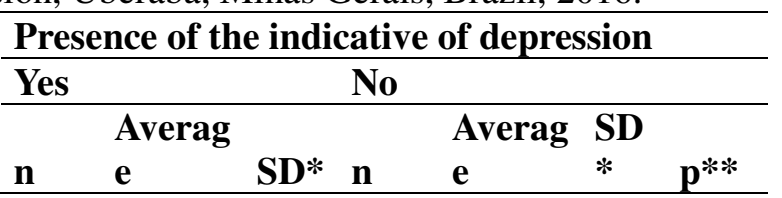



$\begin{array}{lllll}38 & 0.6 & 1.6 & 102 & 1.4\end{array}$ 
3.2. Performing specific physical activities (walking, swimming, etc.)

\section{Blood sugar monitoring}

$\begin{array}{lllllll}38 & 0.3 & 1.2 & 102 & 1 & 2.1 & 1\end{array}$

4.1. Evaluating Blood Sugar

\section{(3.}

4.2. Evaluating blood sugar the recommended number of times

38

1.4

$2.1 \quad 102 \quad 1.4$

2.31

0.92

5. Foot care

\subsection{Feet examination}

5.2. Examination inside the shoes before putting them on

5.3. Drying the spaces between the toes after washing them

\section{Medication}

Regarding the number of morbidities, the items of "following a healthy diet", "performing physical activities for at least 30 minutes" and "performing specific physical activities (walking, swimming, etc.)" showed a significant correlation, with significance levels $p=0.031, p=0.003$ and $p=$ 0.005 respectively. Data showed that adherence increased as the number of morbidities decreased. However, the elderly with the highest number of diseases had more adherence to the "Feet examination" ( $p=0.005)$ and "examination of the shoes before putting them on" $(p=0.005)$. The correlations mentioned were considered weak.

The education level was related to the three items of the foot care dimension: "feet examination" $(\mathrm{p}=0.002)$, "examination of the shoes before putting them on" $(\mathrm{p}=0.007)$ and "dry the spaces between the toes after washing them" $(p=0.028)$, and the adherence was higher in the elderly with higher school level. The correlations were classified as weak.

When considering their income, the correlated items were "following a healthy diet" ( $p$ $=0.038)$ and "performing physical activities for at least 30 minutes" $(p=0.006)$. The results showed that older people with higher incomes had more adherence to these activities (direct correlation, of weak magnitude).

The analysis of the simultaneous contribution of the predictors gender, education level, indicative of depression and number of morbidities through the multiple linear regression model showed that the item "Intake of five or more servings of fruits and/or vegetables" was significantly associated with the gender $(p=0.041)$, indicating that women had a higher average adherence than men in this activity. The number of morbidities was significantly associated with the items "performing physical activities for at least 30 minutes" ( $(p=0.02)$ and "performing specific physical activities (walking, swimming, etc.)" (p = 0.008), indicating increased adherence to these activities as the number of morbidities decreases.

The school level and the number of morbidities were significantly associated with the items "feet examination" $(\mathrm{p}=0.00$ and 0.001 , respectively), "examination inside the shoes before putting them on" ( $\mathrm{p}=0.001$ and 0.00 , respectively) and "drying the spaces between the toes after washing them" ( $\mathrm{p}=0.018$ and 0.027 , respectively), showing that as school level and the number of morbidities increase, the adherence of foot care activities also increases. The item "examination inside the shoes before putting them on" showed a significant association with the indicative of depression $(p=0.039)$, showing that the mean adherence increased as depressive symptoms decreased.

The other factors did not have a significance index and may not influence adherence to self-care with DM. The following table shows the data produced by multivariate analysis (Table 4 ). 
Table 4. Final multiple linear regression models for predictors associated with diabetes self-care activities adherence, Uberaba, Minas Gerais, Brazil, 2016.

\section{QAD items}

\section{Predictors}

1. General food

$\begin{array}{llllllllll}\text { 1.1. Following a healthy diet } & 0.0 & 0.8 & - & 0.74 & & & & \\ & 22 & 02 & 0.028 & 1 & 0.101 & 0.251 & -0.168 & 0.062 \\ \text { 1.2. Following food guidance } & & 0.9 & - & 0.89 & & & & \\ & -0 & 76 & 0.011 & 8 & 0.099 & 0.264 & 0.057 & 0.532\end{array}$

2. Specific Food

2.1. Intake of five or more servings of fruits $0.1 \mathbf{0 . 0} \quad 0.16$

and/or vegetables. $\quad \begin{array}{lllll}79 & \mathbf{4 1} & 0.116 & 9\end{array}$

2.2. Intake of red meat and/or whole milk 0.0 0.6 - 0.84

$\begin{array}{llllllllll}\text { derivatives } & 39 & 67 & 0.018 & 1 & -0.013 & 0.885 & -0.014 & 0.874\end{array}$

$\begin{array}{llllllllll}\text { 2.3. Sweet intake } & 0.0 & 0.2 & & 0.53 & & & & & \\ & 93 & 99 & 0.054 & 4 & 0.067 & 0.447 & -0.077 & 0.397\end{array}$

3. Physical activity

3.1. Performing physical activities for at least $30 \quad 0.1 \quad 0.1 \quad-\quad 0.39$

$\begin{array}{lllll}\text { minutes } & 3 & 25 & 0.071 & 5\end{array}$

3.2. Performing specific physical activities $0.0 \quad 0.3 \quad-\quad 0.29$

(walking, swimming, etc.)

$\begin{array}{llllllll}81 & 45 & 0.088 & 3 & 0.135 & 0.117 & -0.236 & \mathbf{0 . 0 0 8}\end{array}$

\section{Blood sugar monitoring}

4.1. Evaluating Blood Sugar

$\begin{array}{lll}0.0 & 0.4 & 0.45\end{array}$

4.2. Evaluating blood sugar the recommended $0.0 \quad 0.9$ number of times

$\begin{array}{llllllll}7 & 65 & 0.064 & 8 & -0.019 & 0.829 & -0.062 & 0.496\end{array}$

5. Foot care

0.98

5.

5.1. Feet examination

$\begin{array}{ll}0.0 & 0.4 \\ 7 & 06\end{array}$

5.2. Examination inside the shoes before putting

$\begin{array}{ll}7 & 06 \\ & 0.2\end{array}$

them on

$-0.1 \quad 15$

0.298

$\mathbf{0}$
$\mathbf{0 . 0 0}$

$\begin{array}{lll}-0.064 & 0.434 & 0.28\end{array}$

0.001

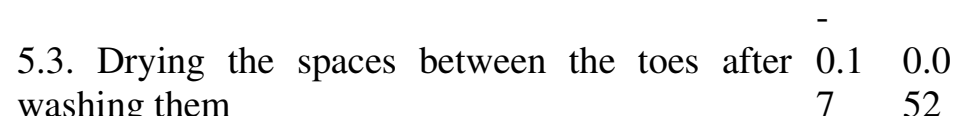

0.2591

0.17

$\mathbf{0 . 0 3 9} 0.339$

$\mathbf{0}$ washing them

$\begin{array}{llll}7 & 52 & 0.199 & 8\end{array}$

0.01

\section{Medication}

$\begin{array}{lll}0.1 & 0.73\end{array}$

6.2. Taking insulin injections as recommended

$\begin{array}{llllllll}-0.3 & 19 & 0.06 & 9 & 0.073 & 0.694 & 0.236 & 0.22\end{array}$

$\begin{array}{llll}0.1 & 0.1 & - & 0.83\end{array}$

6.3. Taking the indicated number of diabetes pills. $\begin{array}{llllll}4 & 36 & 0.018 & 5 & 0\end{array}$

$* \beta$ : standardized linear regression coefficient; $* * p<0.05$.

\section{DISCUSSION}

Similar to other findings in the literature, the distribution according to gender may be justified by the higher life expectancy compared to men, showing an increase in this population (ROSSET et al., 2011). The significant number of women in the elderly population is linked to less exposure to violence, risks in the workplace, and lower consumption of alcohol and tobacco (BANDEIRA; MELO; PINHEIRO, 2010). Also, they are more assiduous to health services because they are more attentive to health issues and aware of the importance of monitoring with health professionals, 
Factors related...

favoring early diagnosis (MEDEIROS; MORAIS, 2015), contributing to the fact that women have a higher proportion of diabetes diagnosis reports than men (INSTITUTO BRASILEIRO DE GEOGRAFIA ESTATÍSTICA, 2014a).

Regarding the average age, there is a prevalence of DM in the elderly over 65 years old, affecting $21.6 \%$ of this population in Brazil, in which the age group from 65 to 74 is the most affected with $19.9 \%$ of cases (INSTITUTO BRASILEIRO DE GEOGRAFIA ESTATÍSTICA, 2014a), the predominant age of this study. This data highlights the need for readjustment of health policies aimed at stimulating healthy aging through the creation of health education groups, promotion of physical, cultural, and recreational activity (PILGER; MENON; MATHIAS, 2011).

The Registration and Monitoring System of Hypertensive and Diabetic (HIPERDIA) of the Unified Health System (SUS) stands out as a monitoring group of the population, assisting the population with these diseases in Primary Health Care, which allows acquisition, dispensation and distribution as well as regular and systematic care to all registered patients (DATASUS, 2019).

Regarding their marital status, the highest percentage without a partner showed the importance of nurses in the training of the older people, aiming at self-care through educational activities, nursing consultations or home visits (TAVARES et al., 2011). It is also important to clarify the need to identify potential caregivers, especially among family members.

Regarding their education level and income, this study showed higher average education and individual income than the elderly Brazilian population, which corresponds to 4.7 years of school and monthly income between half and one minimum wage (INSTITUTO BRASILEIRO DE ESTATÍSTICA E GEOGRAFIA, 2014b). This result may be partly related to the fact that it is a more privileged region compared to the rest of the country.

Low education and income are associated with lower demand for health services, lower access to medicines and lower adherence to treatment (MANTOVANI; LUCCA; NERI, 2015), which leads to the onset of chronic diseases (STOPA et al., 2015) and hindering the understanding of treatment guidelines and negatively reflecting on the practice of self-care activities for DM (LUZ, 2014).

The average morbidity of this study was higher than a study conducted in Belém, with an average of $4.5( \pm 2.0)$ of morbidity per older person (FREITAS et al., 2016). In another study conducted
DYONISIO, G. et al.

in the interior of São Paulo, most elderly participants $(53.5 \%)$ had between one and three diseases (DEGANI et al., 2014).

The high number of morbidities per individual observed in this study confirmed the need for regular health care with these older people. These services should be based not only on curative activities but also on prevention and health education actions, aiming at the acquisition of healthy habits to avoid the onset of diseases or to avoid the complications arising from them (VERAS, 2012; PILGER; MENON; MATHIAS, 2011).

Regarding the polypharmacy, this index was lower than research conducted in Belém of 6.8 medications per older person (CUENTRO et al., 2016). It is a multifactorial condition, closely related to the presence of multi-morbidities and associated clinical manifestations. It also increases the risk and severity of adverse reactions, which can cause cumulative toxicity, impairing treatment adherence and increasing hospitalizations and mortality (SECOLI, 2010). In this context, we highlight the important role of the family health teams who not only do visits but can monitor the patients by the HIPERDIA group and routine consultations in health facilities.

Regarding the indicative of depressive symptoms, people with DM are at least three times more likely to become depressive. Depression is usually a comorbid condition of DM, a direct consequence of neurochemical changes caused by the disease, and it is often underdiagnosed since the symptoms of both are similar and often attributed only to DM (STARKSTEIN et al., 2014).

$\mathrm{DM} /$ depression comorbidity is associated with the advanced age, with a negative impact on health, well-being, decline in functional skills, and self-care (GEMEAY et al., 2015; OSBORN; EGEDE, 2012). Depression may also lead to worsening glycemic control that in turn contributes to the worsening of the depressive condition (MUTVITCU et al., 2016). The screening for the indicative of depression should be frequent in professional practice and health referral services, especially in those who perform monthly DM monitoring, offering help and treatment for symptoms of depression.

The QAD was used to assess the frequency of adherence to DM self-care activities, considering the last seven days before the interview.

The physical activity domain is highlighted among the lower average domains, in which the item "performing physical activities for at least 30 minutes" had an average adherence rate of 1.2 days per week, similar to the average in other research 
with 1.6 days a week (TREVISANI, 2014) and 1.5 days a week (ROOS, BAPTISTA; MIRANDA, 2015), but below the average of 2.4 days a week (COELHO, 2013), who found an average of 3.9 days a week (SANTOS et al., 2014) and 4.9 days a week (JESUS, 2012).

In the item "performing specific physical activities (walking, swimming, cycling)", the average adherence dropped to 0.9 days per week, lower than in other surveys with averages of 1.1 days per week (ROOS, BAPTISTA; MIRANDA, 2015), 2 days a week (COELHO, 2013) and 1.8 days a week (SANTOS et al., 2014). In another research, the average was 1.6 days per week, remaining the same in both items of the physical activity dimension (TREVISANI, 2014).

Research conducted in Porto Alegre proposed to compare the level of physical activity and exercise-related care in people with DM, and the results showed that those with type 2 DM were more sedentary than those with type $1 \mathrm{DM}$. The reasons for type $2 \mathrm{DM}$ were discomfort, medical restriction and not enjoying physical activity. The justification for those with type $1 \mathrm{DM}$ was lack of time, laziness, and hypoglycemia. Only $38.8 \%$ performed self-care such as feeding, stretching, capillary blood sugar monitoring (DUARTE et al., 2012). A study with older people with diabetes in Teresina found that $68.8 \%$ of them did not practice physical activity (ALENCAR et al., 2014).

The practice of 150 minutes of moderateintensity exercise or 75 minutes of high-intensity activities per week is recommended. Regular physical activity reduces body weight, controls glycemic, reduces cholesterol, and reduces the risk for CVD (INSTITUTO BRASILEIRO DE ESTATÍSTICA E GEOGRAFIA, 2014b). Physical activity should be recommended by health professionals to encourage participation in supervised walking groups or other programs available in communities.

Blood sugar monitoring was another domain of lower adherence in which the item "evaluating blood sugar" showed adherence of 1.4 days per week, similar to the results found in Florianópolis of 1.8 days per week (MICHELS et al., 2010) and Treviso-SC with 1.2 days a week (JESUS, 2012). Higher averages were observed in other studies with 3.98 days per week (SANTOS et al., 2014), 4.5 days per week (COELHO, 2013), and 5.4 days per week (TREVISANI, 2014). "Evaluating blood sugar as recommended" had an average of 1.2 days per week, similar to another survey of 1.37 days per week (MICHELS et al., 2010). A higher adherence was observed in other investigations whose average was 3.32 days per week (COELHO, 2013), 3.46 days per week (SANTOS et al., 2014), and 5.5 days per week (TREVISANI, 2014).

Blood sugar monitoring is a fundamental part of DM management since it is a parameter for conducting treatment, allowing dose adjustments or changes in drug prescriptions, and determining the physical activity plan and dietary guidelines (ADENIYI et al., 2015). It works as an educational tool, allowing the person evaluating the causes of hypo or hyperglycemia. However, the self-cost and inconvenience of the method and the lack of knowledge of the importance of self-monitoring of blood sugar hinder this activity adherence (ROOS; BAPTISTA; MIRANDA, 2015). This result is partly justified because they are older people with limited financial resources, a condition that may hinder their access to blood sugar monitoring, restricted to HIPERDIA consultations only.

Capillary blood sugar monitoring is recommended three or more times a day for all people with DM taking multiple doses of insulin. For individuals with type 2 DM taking oral antidiabetics, routine monitoring is not recommended (AMERICAN DIABETES ASSOCIATION, 2015).

The medication dimension was the one with the highest average adherence. The item "taking insulin injections as recommended" had an average of 6.2 days per week. Other studies have found averages of 6.9 (GOMIDES et al., 2013), 6.16 days a week (ROOS; BAPTISTA; MIRANDA, 2015), and 5.86 days a week (SANTOS et al., 2014). The item "taking the indicated number of diabetes pills" had an average of 6.6 days per week. Approximate results were found in other studies with averages of 6.65 days per week (COELHO, 2013) and 6.09 days per week (SANTOS et al., 2014). Another research obtained an average of 4.5 days per week (TREVISANI, 2014), lower than in this study; however, one study showed total adherence with seven days per week (GOMIDES et al., 2013).

A study of 423 patients with diabetes in Passos aimed at evaluating their adherence to drug and non-drug treatment of diabetes found that medication adherence was observed in $84.4 \%$ of the individuals, while the adherence to diet and physical activity was observed in 3 patients $3.1 \%$ and $58.6 \%$ individuals. High adherence to drug treatment was related to the acceptability and belief in the drug's effect on disease control (FARIA et al., 2014). Besides more closely linked to health services, elderly people tend to have greater adherence to drug treatment, which may be related to credibility and confidence in the prescribed medications. Although the prescription of the drug is a medical 
Factors related...

assignment, the health team is very important in the monitoring, guidance, and supervision of drug treatment. Checking doubts and having undesirable effects is the nurse's role, whether in the home nursing consultation or the HIPERDIA group.

As smoking is associated with increased risk of CVD, microvascular complications and premature death, sensitizing to quit smoking is a priority for group and individual activities in the community. Stop smoking in people with diabetes improves metabolic parameters and decreases blood pressure and albuminuria within one year (AMERICAN DIABETES ASSOCIATION, 2015). Although the highest percentage is non-smokers, stop smoking should be encouraged for those who still do it, and a follow-up for those who are in the process of stopping should be done as being a period most likely to relapse. During home visits, the health team can identify the difficulties and doubts regarding smoking cessation.

The multivariate analysis considered the predictors of gender, education level, indicative of depression, and the number of morbidities for the outcome adherence to diabetes self-care.

Gender was significantly associated with the item "intake of five or more servings of fruits and/or vegetables," showing greater adherence in women. This result was also verified in other studies in which the accomplishment of food control was more prevalent in females (ROSSANEIS et al., 2016), as well as a higher consumption of fruits and vegetables (DOUBOVA et al., 2016; MENDES et al., 2011; SILVEIRA et al., 2015).

Women appeared to be more concerned about healthy eating and weight control, which explains the difference in eating behavior patterns when compared to men (SILVEIRA et al., 2015).

A study in Porto Alegre described the frequency of adherence to diet and analyzed its association with depression in the elderly population with metabolic syndrome and found that 72 participants $(66.1 \%)$ were classified as non-adherent and $37(33.9 \%)$ were considered adherent. In the depressed elderly participants, adherence to the guidelines to avoid the consumption of sweets and sugar was lower (JACONDINO et al., 2016).

Considering that eating behavior is difficult to change, the promotion of healthy eating and the consumption of fruits and vegetables should be insistently encouraged by health professionals (with priority for young people, low-income and loweducated individuals) having to reduce the burden of diseases attributed to malnutrition (CHAFFEE, 2014).
DYONISIO, G. et al.

The correlation between the number of morbidities and the items "performing physical activities for at least 30 minutes" and "performing specific physical activities (walking, swimming, etc.)" suggested that physical activity adherence increases the number of morbidities proportionally. This finding was also found in another study with elderly participants (VIRTUOSO et al., 2012) in which those with the highest number of morbidities reported greater difficulty in performing physical activity, showing the necessary incentive to participate in physical activities in the community.

A study conducted in Montes Claros identified a high prevalence of physical inactivity (57.1\%) among the elderly participants. According to this research, physical inactivity is related to the reduction of functional capacity in old age, therefore, increasing dependence for help from other people and limiting their autonomy to perform activities of daily living and leisure. The presence of morbidities can be understood as a limiting factor of physical activity as well as a consequence of inactivity. Physical activity has a strong impact on the prevention of Non-communicable Chronic Diseases (NCDs) and better quality of life (OLIVEIRA-CAMPOS; MACIEL; NETO, 2012).

However, a correlation between the number of morbidities and foot care indicated that adherence to this activity increased proportionally to the increase in the number of morbidities. The presence of comorbidities and complications resulting from poor metabolic control may contribute to the low motivation for self-care (BAQUEDANO et al., 2010). Also, older people commonly have a visual impairment, joint limitations, and spinal problems, hindering to inspect and perform foot care (CISNEROS; GONÇALVES, 2011). Although it was not the objective of this study, certain morbidities and DM cause sequels that can limit the senses and movements, besides causing discomfort and pain, reasons that may interfere with foot care.

The education level is related to the three items of the foot care dimension. This result was similar to other research that also found this association (COELHO, 2013). However, another study found a discordant result, in which self-care measures correlated inversely with education level (GOMES-VILAS BOAS et al., 2012).

School-level is directly related to self-care, and the access and use of health services, as low education may prevent or hinder the assimilation of guidance given by health professionals to self-care and the acquisition of new life habits (GOMIDES et al. al., 2013). 
Diabetic foot is one of the most common complications of DM and often results in amputation of the affected limb. Knowing about risks is essential for proper prevention. Educational and care actions that prioritize regular foot examination, risk classification, and therapeutic education significantly reduce the occurrence of foot ulcers (CUBAS et al., 2013).

Depressive symptoms were associated with the item "examination inside the shoes before putting them on," and the elderly participants who did not show depression showed greater adherence to this activity.

People with diabetes showing depressive symptoms neglect foot care and may have a significant loss of protective plantar sensitivity (MICHELS et al., 2010) and a six times greater risk of foot ulceration than non-depressive people diabetes (COELHO et al., 2014).

Depression is associated with nonparticipation in health education programs, inadequate diet, irregular medication use, physical inactivity, and, consequently, the higher number of associated morbidities, complications, and increased mortality (COELHO et al., 2014; TENG; HUMES DEMETRIO, 2005). Therefore, an ineffective selfcare is often associated with the presence of depressive symptoms (MUT-VITCU et al., 2016; ROY; LLOYD, 2012; WEINGER, BEVERLY, SMALDONE, 2014).

The results showed that the low average adherence in almost all self-care activities is often associated with the lack of guidance related to selfcare and lack of knowledge of the consequences of non-adherence to DM treatment. The lack of health education has a direct impact on adherence to the treatment plan, impairing the quality of life of older people with DM.

The multivariate analysis verified the simultaneous contribution of the predictors of gender, education level, indicative of depression, and the number of morbidities in the adherence to self-care activities. The following correlations were observed: between gender and the activity "intake of five or more servings of fruits/vegetables", indicating greater female adherence; between the number of morbidities and the items "performing physical activities for at least 30 minutes" and "performing specific physical activities (walking, swimming, etc.)" suggesting that adherence to physical activity proportionally decreases the number of morbidities; between education level and number of morbidities and foot care-related items (feet examination, examination inside the shoes before putting them on and drying the spaces between the toes after washing them), suggesting that adherence increases proportionally with increasing school level and decreasing as the number of morbidities increases; and between the indicative of depression and the item "examination inside the shoes before putting them on", showing that adherence to this activity increases as depressive symptoms decrease.

The results of this research showed good adherence to DM control medications and poor adherence to non-medication measures, especially diet, regular physical activity, blood sugar monitoring, and foot care. It can be concluded that the factors that influence adherence to self-care are gender, education level, the number of morbidities and indicative of depression.

The role of the multi-professional health team is very important to identify both problems and potentialities with elderly people with diabetes and their relatives/caregivers to ensure satisfactory adherence to self-care activities. The continuing education of these professionals is extremely necessary for them to understand the importance of adhering to such activities and to be able to provide guidance and awareness about the adoption of healthy habits.

Nurses are among all health professionals that, in addition to scientific knowledge, have strategies such as home visits, nursing consultations, and health education operative groups to identify problems, monitor the individual, and stimulate the practice of self-care, determining the necessary interventions considering the individuality of each one.

A limitation of this study was the crosssectional approach that prevents the establishment of causal relationships, especially to determine the temporal precedence of one variable over another. However, this research contributed to the expansion of knowledge regarding adherence to self-care activities of DM in the elderly population and the factors associated with it, considering that few studies addressed this issue in the elderly population.

Thus, these findings may contribute to health professionals, especially nursing professionals, helping them to identify problems and potentialities for self-care in the elderly population. They should guide the planning of educational actions considering their age, education level, income, the presence or absence of a partner, physical and cognitive limitations, but always emphasized that the individual is the major responsible for their health. 
RESUMO: O tratamento do diabetes mellitus é complexo e envolve diversas atividades. Seu objetivo é controlar a doença e evitar complicações. Parte do sucesso do tratamento está na adesão ao autocuidado. $\mathrm{O}$ objetivo desse estudo foi identificar os fatores relacionados à adesão às atividades de autocuidado em idosos comunitários com diabetes. Estudo transversal, observacional e analítico com abordagem quantitativa dos dados, realizado com 140 idosos. Foram utilizados os instrumentos: Mini Exame do Estado Mental para avaliação cognitiva, instrumento de caracterização sociodemográfica e clínica, Questionário Brasileiro de Avaliação Funcional e Multidimensional para verificação das morbidades autorreferidas, Escala de Depressão Geriátrica Abreviada para investigação da presença de sintomas depressivos e Questionário das Atividades de Autocuidado do Diabetes que avaliou a adesão a atividades relacionadas ao auto manejo de diabéticos. Os resultados deste estudo apontam que atividades de autocuidado com maior adesão foram: "tomar o número indicado de comprimidos do diabetes" $(6,6 \pm 1,2)$, "tomar injeções de insulina conforme recomendado" $(6,2 \pm 2,0)$, " secar os espaços entre os dedos dos pés depois de lavá-los" $(4,6 \pm 3,2)$ e "seguir uma dieta saudável" $(4,5 \pm 2,7)$ e as menores foram "realizar atividades físicas específicas (caminhar, nadar, etc)" $(0,9 \pm 1,9)$, "realizar atividades físicas por pelo menos 30 minutos" $(1,2 \pm 2,2)$, "avaliar o açúcar no sangue o número de vezes

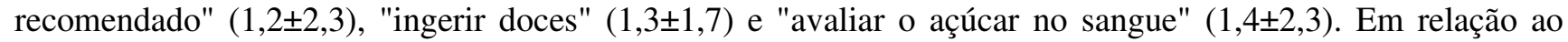
tabagismo, 88,6\% não eram fumantes. Os fatores que se apresentaram relacionados às medidas de autocuidado foram: sexo, indicando maior adesão das mulheres; escolaridade e número de morbidades, sugerindo a adesão ao domínio cuidado como os pés é diretamente proporcional à escolaridade e o número de morbidades; no entanto, este mesmo domínio apresentou-se inversamente proporcional ao indicativo de depressão, indicando que houve maior adesão entre os que não apresentaram sintomas depressivos. Os fatores associados à adesão das atividades de autocuidado observados nessa pesquisa contribuem para o planejamento de estratégias que visem prevenir complicações do diabetes mellitus e promovam melhorias na vida e saúde dos idosos da comunidade.

PALAVRAS-CHAVE: Saúde do idoso. Diabetes Mellitus. Autocuidado. Cooperação e adesão ao tratamento.

\section{REFERENCES}

ADENIYI, O. V; YOGESWARAN, P.; WRIGHT, G.; LONGO-MBENZA, B.Diabetic patients' perspectives on the challenges of glycaemic control. Afr J Prm Health Care Fam Med., v.7, n.1, p. 1-8, 2015.

https://doi.org/10.4102/phcfm.v7i1.767

ALENCAR, L. L; TORRES, M. V.; SANTOS, A. M. B.; SANTOS, M. B.; SANTIAGO, A. K. C.; BARBOSA, A. P. B.Perfil epidemiológico de idosos com diabetes mellitus tipo 2 cadastrados na estratégia saúde da família. Revista Eletrônica Gestão \& Saúde, p.2972-89, 2014.

ALMEIDA, O.P.; ALMEIDA, S.A. Confiabilidade da versão brasileira da Escala de Depressão em Geriatria (GDS) versão reduzida. Arquivos de Neuropsiquiatria, v. 57, n. 2-B, p. 421-26, 1999.

https://doi.org/10.1590/S0004-282X1999000300013

AMERICAN DIABETES ASSOCIATION (ADA). Standards of Medical Care in Diabetes - 2015. Diabetes Care, v.38, Suppl1, p.S1-S94. 2015. https://doi.org/10.2337/dc15-S003

BANDEIRA, L.; MELO, H. P.; PINHEIRO, L. S. Mulheres em dados: o que informa a PNAD/IBGE, 2008. In: Observatório Brasil da Igualdade de Gênero, p. 107-119, 2010.

BAQUEDANO, I. R.; SANTOS, M. A.; TEIXEIRA, C. R. S.; MARTINS, T. A.; ZANETTI, M. L. Fatores relacionados ao autocuidado de pessoas com diabetes mellitus atendidas em Serviço de Urgência no México. RevEscEnferm USP, v.44, n.4, p.1017- 23, 2010. https://doi.org/10.1590/S0080-62342010000400023

BERTOLUCCI, P. H.; BRUCKI, S. M. D.; CAMPACCI, S. R.; JULIANO, Y. O mini-exame do estado mental em uma população geral: impacto da escolaridade. Arquivos de Neuropsiquiatria, v. 52, p. 1-7, 1994.

https://doi.org/10.1590/S0004-282X1994000100001 
BRASIL. Ministério da Saúde. Secretaria de Atenção à Saúde. Departamento de Atenção Básica. Estratégias para o cuidado da pessoa com doença crônica: diabetes mellitus. Brasília: Ministério da Saúde, 2013b. 160 p.

BUB, M. B. C.; MEDRANO, C.; SILVA, C. D.; WINK, S.; LISS, P. E.; SANTOS, E. K. A. A noção de cuidado de si mesmo e o conceito de autocuidado na enfermagem. Texto Contexto Enferm, v.15, p. 152-7, 2006. https://doi.org/10.1590/S0104-07072006000500018

CHAFFEE, B. W. Fatores nos primeiros anos de vida que influenciam o consumo de frutas e verduras entre crianças. J Pediatr. v.90, n.5, p.437-439, 2014.

CISNEROS, L. L.; GONÇALVES, L. A. Educação terapêutica para diabéticos: os cuidados com os pés na realidade de pacientes e famílias. Ciência \& Saúde Coletiva, v.16, n.1, p.1505-1514, 2011. https://doi.org/10.1590/S1413-81232011000700086

COELHO, A. C. M. Autocuidado das pessoas com diabetes mellitus tipo 2 em seguimento ambulatorial. 2013. 112f. Dissertação (Mestrado) - Escola de Enfermagem de Ribeirão Preto, Universidade de São Paulo, Ribeirão Preto, 2013.

COELHO, C. R.; ZANTUT-WITTMANN, D. E.; PARISI, M. C.A cross-sectional study of depression and selfcare in patients with type 2 diabetes with and without foot ulcers. Ostomy Wound Manage, v.60, n.2, p.46-51, 2014.

COHEN, J. Statistical power analysis for the behavioral sciences. 2 ed. Hillsdale, NJ: Lawrence Erlbaum Associates, 1988.

CUBAS, M. R.; SANTOS, O. M.; RETZLAFF, E. M. A.; TELMA, H. L. C.; ANDRADE, I. P. S. Pé diabético: orientações e conhecimento sobre cuidados preventivos. Fisioter. Mov., v. 26, n. 3, p. 647-655, 2013. https://doi.org/10.1590/S0103-51502013000300019

CUENTRO, V. S.; MODESTO, T; ANDRADE, M. A.; SILVA, M. V. S.Prevalência e fatores associados à polifarmácia entre idosos de um hospital público. Revista contexto \& saúde, v. 16 n. 30, p. 28-35, 2016. https://doi.org/10.21527/2176-7114.2016.30.28-35

DEGANI, G. C.; PEREIRA JÚNIOR, G. A.; RODRIGUES, R. A. P.; LUCHESI, B. M.; MARQUES, S. Idosos vítimas de trauma: doenças preexistentes, medicamentos em uso no domicílio e índices de trauma.

RevBrasEnferm., v.67, n.5, p.759-65, 2014. https://doi.org/10.1590/0034-7167.2014670513

DIAS, A. M.; CUNHA, M.; SANTOS, A. M. M.; NEVES, A. P. G.; PINTO, A. F. C.; SILVA, A. S. A.; CASTRO, S. A. Adesão ao regime terapêutico na doença crônica: revisão da literatura. Millenium, v. 40, p. 201-219. 2011.

DOUBOVA, S. V.; SÁNCHES-GARCÍA, S.; INFANTE-CASTAÑEDA, C.; PÉRZ-CUEVAS, R. Factors associated with regular physical exercise and consumption of fruits and vegetables among Mexican older adults. BMC Public Health, v.16, n.952, 2016. https://doi.org/10.1186/s12889-016-3628-2

DUARTE, C. K. ALMEIDA, J. C.; MERKER, A. J. S.; BRAUER, F. O.; RODRIGUES, T. C.Nível de atividade física e exercício físico em pacientes com diabetes mellitus. RevAssocMed Bras., v.58, n.2, p.215221, 2012. https://doi.org/10.1590/S0104-42302012000200018

FARIA, H. T. G.; RODRIGUES, F. F. L.; ZANETTI, M. L.; MOURA, M. F.; DAMASCENO, M. M. C.Factors associated with adherence to treatment of patients with diabetes mellitus. Acta Paul Enferm., v. 26, n.3, p.231-247, 2013. https://doi.org/10.1590/S0103-21002013000300005 
FARIA, H. T. G.; SANTOS, M. A.; ARRELIAS, C. C. A.; RODRIGUES, F. F. L.; GONELA, J. T.; TEIXEIRA, C. R. S.; ZANETTI, M. L.Adesão ao tratamento em diabetes mellitus em unidades da Estratégia Saúde da Família.RevEscEnferm USP, v.48, n.2, p.257-63, 2014. https://doi.org/10.1590/S0080623420140000200009

FREITAS, C. V.; SARGES, E. S. N. F.; MOREIRA, K. E. C. S.; CARNEIRO, S. R. Avaliação de fragilidade, capacidade funcional e qualidade de vida dos idosos atendidos no ambulatório de geriatria de um hospital universitário. Rev. Bras. Geriatr. Gerontol., v.19, n.1, p.119-128, 2016.

GEMEAY, E. M.; MOAWED, S. A.; MANSOUR, E. A.; EBRAHIEM, N. E.; MOUSSA, I. M.; NADRAH, W. O. The association between diabetes and depression. Saudi Med J., v.36, n.10, p.1210-1215, 2015. https://doi.org/10.15537/smj.2015.10.11944

GOMIDES, D. S.; VILAS-BOAS, L. C. G.; COELHO, A. C. M.; PACE, A. E.Autocuidado das pessoas com diabetes mellitus que possuem complicações em membros inferiores. Acta Paul Enferm., v.26, n.3, p.289-93, 2013. https://doi.org/10.1590/S0103-21002013000300014

INSTITUTO BRASILEIRO DE GEOGRAFIA E ESTATÍSTICA (IBGE). Pesquisa Nacional de Saúde 2013: Percepção do estado de saúde, estilos de vida e doenças crônicas. 2014. Brasília-DF: Ministério do Planejamento, Orçamento e Gestão, 2014a. Disponível em:

http://biblioteca.ibge.gov.br/visualizacao/livros/liv91110.pdf (acesso em 13 de agosto de 2015).

INSTITUTO BRASILEIRO DE GEOGRAFIA E ESTATÍSTICA (IBGE). Síntese de Indicadores Sociais: uma análise das condições de vida da população brasileira. 2014. Brasília-DF: Ministério do Planejamento, Orçamento e Gestão, 2014b. Disponível em: http://cebes.org.br/site/wp-content/uploads/2014/12/SIS_2014.pdf (acesso em 13 de agosto de 2015).

INTERNATIONAL DIABETES FEDERATION (IDF). Diabetes Atlas, 6th ed., International Diabetes Federation, Brussels, 2013.

JACONDINO, C. B.; CLOSS, V. E.; GOMES, I.; SCHWANKE, C. H. A.Adesão à dieta por idosos com síndrome metabólica assistidos na Estratégia Saúde da Família: frequência e associação com depressão. Sci Med., v.26, n.3, 2016. https://doi.org/10.15448/1980-6108.2016.3.22956

JESUS, R. A. T. Estado nutricional e adesão ao tratamento de pacientes diabéticos tipo 2 de uma unidade básica de saúde de Trevisco - SC. 2012, 99p, Monografia. Universidade do EstremoSulCatarinense, Criciúma, 2012.

LLOYD, C. The effects of diabetes on depression and depression on diabetes. Diabetes Voice, v.53, n.10, p.236, 2008.

LUZ, E. P. Perfil sociodemográfico e de hábitos de vida da população idosa de um município da região norte do Rio Grande do Sul, Brasil. Rev. Bras. Geriatr. Gerontol., v.17, n.2, p. 303-314, 2014. https://doi.org/10.1590/S1809-98232014000200008

MANTOVANI, E. P.; LUCCA, S. R.; NERI, A. L. Autoavaliação negativa de saúde em idosos de cidades com diferentes níveis de bem-estar econômico: dados do Estudo FIBRA. Ciênc. saúde coletiva, v. 20, n. 12, p. 3653-3668, 2015. https://doi.org/10.1590/1413-812320152012.20492014

MEDEIROS, S. G; MORAIS, F. R. R. Organization of healthcare services for elderly women: users' perceptions. Interface, v. 19, n. 52, p. 109-19. 2015. https://doi.org/10.1590/1807-57622014.0264 
MENDES, T. A. B.; GOULBAUM, M.; SEGRI, N. J.; BARROS, M. B. A.; CESAR, C. L. G.; CARANDINA, L.; ALVES, M. C. G. P.Diabetes mellitus: fatores associados à prevalência em idosos, medidas e práticas de controle e uso dos serviços de saúde em São Paulo, Brasil. Cad. Saúde Pública, v.27, n.6, p.1233-1243, 2011. https://doi.org/10.1590/S0102-311X2011000600020

MICHELS, M. J.; CORAL, M. H. C.; SAKAE, T. M.; DAMAS, T. B.; FURLANETTO, L. M.Questionário de Atividades de Autocuidado com o Diabetes: tradução, adaptação e avaliação das propriedades psicométricas. ArqBrasEndocrinolMetab., v.54, n.7, p.644-651, 2010. https://doi.org/10.1590/S0004-27302010000700009

MUT-VITCU, G.; TIMAR, B.; TIMAR, R.; OANCEA, C.; CITU, I. C.Depression influences the quality of diabetes-related self-management activities in elderly patients with type 2 diabetes: a cross-sectional study. ClinicalInterventions in Aging, v.11, p. 471-479, 2016. https://doi.org/10.2147/CIA.S104083

OLIVEIRA-CAMPOS, M.; MACIEL, M. G.; NETO, J. F. R. Atividade física insuficiente: fatores associados e qualidade de vida. RevBrasAtivFis e Saúde, v.17, n.6, p.562-572, 2012. https://doi.org/10.12820/23171634.2012v17n6p562

ORGANIZAÇÃO MUNDIAL DA SAÚDE (OMS). Adesão às terapias de longa duração: evidência para a prática. Genebra, 2003.

ONG, W. N.; CHUA, S. S.; NG, C. J. Barriers and facilitators to self-monitoring of blood sugar in people with type 2 diabetes using insulin: a qualitative study. Patient Prefer Adherence, v.15, n. 8, p. 237-246, 2014. https://doi.org/10.2147/PPA.S57567

OSBORN, C.Y.; EGEDE, L. E. The Relationship between Depressive Symptoms and Medication NonAdherence in Type 2 Diabetes: The Role of Social Support. GenHospPsychiatry, v. 34, n.3, p.249-253, 2012. https://doi.org/10.1016/j.genhosppsych.2012.01.015

PARADELA, E. M. P. Depressão em idosos. Revista Hospital Universitário Pedro Ernesto, UERJ, p. 31-40, 2011.

PILGER, C.; MENON, M. H; MATHIAS, T. A. F. Características sociodemográficas e de saúde de idosos: contribuições para os serviços de saúde. Rev. Latino-Am. Enfermagem. v. 19, n. 5, p. 01-09, 2011.

RAMOS, L. R. Growing old in São Paulo, Brazil: assessment of health status and family support of the elderly of different socio-economic strata living in the community. Theses (Doctor) - London School of Hygiene and Tropical Medicine, London. 1987.

REZENDE NETA, D. S.; SILVA, A. R. V.; SILVA, G. R. F. Adesão das pessoas com diabetes mellitusao autocuidado com os pés. RevBrasEnferm., v.68, n.1, p.111-6, 2015. https://doi.org/10.1590/0034$7167.2015680115 \mathrm{p}$

RODRIGUES, L. R.; TAVARES, D. S.; DIAS, F.A.; PEGORARI, M. S.; MARCHIORI, G. F; TAVARES, D. M. S. Qualidade de vida de idosos comunitários e fatores associados. Rev. Enferm UFPE v. 11, Supl. 3, p:1430-8, 2017.

ROOS, A. C.; BAPTISTA, D. R.; MIRANDA, R. C. Adesão ao tratamento de pacientes com Diabetes Mellitustipo 2. Demetra, v.10, n.2, p. 329-346, 2015. https://doi.org/10.12957/demetra.2015.13990

ROSSANEIS, M. A.; HADDAD, M. C. F. L.; MATHIAS, T. A. F.; MARCON, S. S.Diferenças entre mulheres e homens diabéticos no autocuidado com os pés e estilo de vida.Rev. Latino-Am. Enfermagem, v.24, 2016. https://doi.org/10.1590/1518-8345.1203.2761 
ROSSET, I.; RORIZ-CRUZ, M.; SANTOS, J. L. F.; HAAS, V. J.; FABRÍCIO-WEHBE, S. C. C.; RODRIGUES, R. A. P. Diferenciais socioeconômicos e de saúde entre duas comunidades de idosos longevos. Rev. SaúdePública, v. 45, n. 2, p.391-400, 2011. https://doi.org/10.1590/S003489102011000200018

ROY, T.; LLOYD, C. E. Epidemiology of depression and diabetes: a systematic review. J AffectDisord., v.142, n.1, p.S8-S21, 2012. https://doi.org/10.1016/S0165-0327(12)70004-6

SANTOS, G. F. P.; ALMAS, S. P.; FREITAS, L. M.; KAMIL, J. P.; NEMER, A. S. A.A adesão ao autocuidado influencia parâmetros bioquímicos e antropométricos de pacientes diabéticos tipo 2 atendidos no programa hiperdia do município de Juiz de Fora, Minas Gerais, Brasil.Nutr. clin. diet. hosp., v.34, n.3, p.10$19,2014$.

SECOLI, S. R. Polifarmácia: interações e reações adversas no uso de medicamentos por idosos. RevBrasEnf, v.63, n.1, p.136-140, 2010. https://doi.org/10.1590/S0034-71672010000100023

SILVA, C. M. G.; VIDAL, E. C. F. Idosos com diabetes mellitus: práticas de autocuidado. Cad. Cult. Ciênc., v. 10, n. 2, dez. 2011. https://doi.org/10.14295/cad.cult.cienc.v10i2.408

SILVEIRA, E. A.; MARTINS, B. B.; ABREU, L. R. S.; CARDOSO, C. K. S. Baixo consumo de frutas, verduras e legumes: fatores associados em idosos em capital no Centro-Oeste do Brasil. Ciência \& Saúde Coletiva, v.20, n.12, p.3689-3699, 2015. https://doi.org/10.1590/1413-812320152012.07352015

SOCIEDADE BRASILEIRA DE DIABETES (SBD). Diretrizes da Sociedade Brasileira de Diabetes: 20132014. São Paulo: AC Farmacêutica; 2014.

STARKSTEIN, S. E.; DAVIS, W. A.; DRAGOVIC, M.; CETRULLO, V.; DAVIS, T. M. E.; BRUCE, D. G.DiagnosticCriteria for Depression in Type 2 Diabetes: A Data-Driven Approach. PlosOne, v. 9, n.11, 2014. https://doi.org/10.1371/journal.pone.0112049

STOPA, S. R.; MALTA, D. C.; OLIVEIRA, M. M.; LOPES, C. S.; MENEZES, P. R.; KINISHITA, R. T.Prevalência do autorrelato de depressão no Brasil: resultados da Pesquisa Nacional de Saúde, 2013. RevBrasEpidemiol., v.18, n. 2, p.170-180, 2015. https://doi.org/10.1590/1980-5497201500060015

TAVARES, D. M. S.; MARTINS, N. P. F.; DIAS, F. A.; DINIZ, M. A. Qualidade de vida de idosos com e sem hipertensão arterial. Rev. Eletr. Enf., v.13, n.2, p.211-8, 2011. https://doi.org/10.5216/ree.v13i2.10876

TENG, C. T.; HUMES, E. C.; DEMETRIO, F. N. Depressão e comorbidades clínicas. Rev. Psiq. Clín., v.32, n.3, p.149-159, 2005. https://doi.org/10.1590/S0101-60832005000300007

TREVISANI, F. A. Atividades de autocuidado de idosos com diabetes mellitus tipo 2. 2014. $183 \mathrm{f}$.

Dissertação (Mestrado) - Escola de Enfermagem de Ribeirão Preto, Universidade de São Paulo, Ribeirão Preto, 2014.

VERAS, R. P. Prevenção de doenças em idosos: os equívocos dos atuais modelos. Cad. Saúde Pública, v. 28, n. 10, p. 1834-1840, 2012. https://doi.org/10.1590/S0102-311X2012001000003

VIRTUOSO, J. F.; MAZO, G. Z.; MENEZES, E. C.; CARDOSO, A. S.; DIAS, R. G.; BALBÉ, G. P.Perfil de morbidade referida e padrão de acesso a serviços de saúde por idosos praticantes de atividade física.

Ciência\&SaúdeColetiva, v.17, n.1, p.23-31, 2012. https://doi.org/10.1590/S1413-81232012000100005

WEINGER, K.; BEVERLY, E. A.; SMALDONE, A. Diabetes Self-Care and the Older Adult.West J Nurs Res., v.36, n.9, p.1272-1298, 2014. https://doi.org/10.1177/0193945914521696 